\title{
Development of coconut milk residue and jackfruit seed enriched biscuit
}

K. R. Barge and S.P. Divekar

Received : 08.05.2018; Revised : 01.09.2018; Accepted : 19.09.2018

See end of the Paper for authors' affiliation Author for Correspondence :

K. R. Barge

Department of Agricultural Process Engineering, College of Agricultural Engineering and Technology, Dapoli, Ratnagiri (M.S.) India
ABSTRACT : The research was conducted on development of coconut milk residue and jackfruit seed enriched biscuits. Biscuit were prepared with different combination of refined flour, jackfruit seed flour and coconut milk residue flour with two different temperature of baking. The coconut milk residue flour and jackfruit seed flour has high fibres content 46.50 per cent and 3.34 per cent, respectively. Coconut milk residue is by product of coconut milk processing industries such as virgin coconut oil processing industries, flavoured coconut milk industries and coconut milk powder producing industries. Generally jackfruit seed and coconut milk residue thrown as waste and coconut milk residue also used to feeding animals. Coconut milk residue and jackfruit seed have many nutritional and beneficial properties to human health. The total yield of the jackfruit seed flour exclusive of weight of the white arils (2\%), brown spermoderm (8.16\%), handling losses represented 13.34 per cent and when passed through mesh flour yield was documented as $67.50 \mathrm{~g}$. The biscuit containing 50:20:30 and 50:30:20 combination of refined flour, coconut flour and jackfruit seed flour scores more in sensory evaluation. The biscuit colour which are baked at $180{ }^{\circ} \mathrm{C}$ had good colour and apperence than biscuit baked at $200{ }^{\circ} \mathrm{C}$. On addition of coconut sugar instead of common sugar the colour of biscuit is improved. The moisture content of coconut and jackfruit seed biscuit is about 1- 4 per cent. Spread ratio of coconut and jackfruit seed based biscuit is in range of 8 to 10 . The colour of biscuit indicated that, the control biscuit were significantly whiter than the rest.

- KEY WORDS : Coconut milk residue, Jackfruit seed, Enriched biscuit

- HOW TO CITE THIS PAPER : Barge, K.R. and Divekar, S.P. (2018). Development of coconut milk residue and jackfruit seed enriched biscuit. Internat. J. Agric. Engg., 11(2) : 373-378, DOI: 10.15740/HAS/IJAE/11.2/373-378. Copyright@2018: Hind Agri-Horticultural Society. 